\title{
EVALUATION OF COMPOSTED AGRICULTURAL CROP WASTES APPLICATION ON GROWTH, MINERAL CONTENT, YIELD, AND FRUIT QUALITY OF TOMATO
}

\author{
AL-Kahtani $\mathrm{SH}^{1}$, Ahmed MA ${ }^{2,3^{*}}$, Al-Selwey WA ${ }^{2}$, Abdel-Razzak $\mathrm{HS}^{2,4}$ \\ ${ }^{1}$ Department of Agricultural Economics, College of Food and Agricultural Sciences, King Saud University, Kingdom of Saudi Arabia \\ ${ }^{2}$ Department of Plant Production, College of Food and Agricultural Sciences, King Saud University, Kingdom of Saudi Arabia \\ ${ }^{3}$ Department of Horticultural Crops Technology, National Research Center, Dokki 12622-Cairo, Egypt \\ ${ }^{4}$ Vegetable Crops Department, Faculty of Agriculture, Alexandria University, Alexandria, Egypt
}

Received - December 09, 2017; Revision - January 10, 2018; Accepted - February 10, 2018

Available Online - February 20, 2018

DOI: http://dx.doi.org/10.18006/2018.6(1).159.167

KEYWORDS
Crop waste compost
Chlorophyll content
Fruit volume
Mineral concentrations
pH of juice
Sheep manure
Total yield

\begin{abstract}
The effects of different agricultural crop waste composts as organic fertilizer on the growth, leaf chlorophyll content and mineral concentrations, fruit characteristics, yield, and fruit quality aspects of tomato were assessed. The composted crop waste types used were mixture of date palm, olive, and maize (1:1:1) supplemented with 5\% (C2), 10\% (C3), 20\% (C4), and 40\% (C5) of sheep manure as well as the active NPK mineral fertilizer $(\mathrm{C} 1)$ as a check treatment. Results of present study revealed that tomato plants grown in sandy soil amended by combination of compost mixture and $40 \%$ sheep manure (C5) have highest plant height and leaf chlorophyll content as compared to the plants grown in other combinations. Further highest concentration of nitrogen $(\mathrm{N})$, phosphorus $(\mathrm{P})$, potassium $(\mathrm{K})$, Ferrous $(\mathrm{Fe})$, Zink ( $\mathrm{Zn})$ and manganese $(\mathrm{Mn})$ along with fruit yield, and fruit quality were also reported superior in the plant grown in same combination. The percentage increase in the total yield of plants fertilized with C5 was 65.71-65.83\% higher than that of plants fertilized with the compost + NPK (C1). Tomato plants grown in plots amended with compost type C5 had highest shoot dry mass, fruit length, fruit diameter, and fruit juice percentage than plants grown in other treatments. On the other hand, tomato plants under $\mathrm{C} 1$ treatment had higher titratable acidity and $\mathrm{pH}$ of fruit juice as compared to plants grown
\end{abstract}

* Corresponding author

E-mail: maamahmoud@ksu.edu.sa (Ahmed MA)

Peer review under responsibility of Journal of Experimental Biology and Agricultural Sciences.

Production and Hosting by Horizon Publisher India [HPI] (http://www.horizonpublisherindia.in/).

All rights reserved.
All the article published by Journal of Experimental Biology and Agricultural Sciences is licensed under a Creative Commons Attribution-NonCommercial 4.0 International License Based on a work at www.jebas.org.

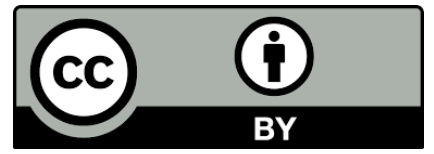


under other compost types. These results indicate that amending sandy soil with compost (date palm, olive, and maize) enriched with higher rates of sheep manure (20\% and $40 \%)$ can increase growth, fruit weight, fruit volume, and yield besides improving the fruit quality characteristics of tomato.

\section{Introduction}

Use of organic farming systems to produce vegetable crops has become more attractive during recent years because of either increased consumer demand for organically produced products or the interest of farmers to sustain or maintain soil health (Dimitri \& Greene, 2002; Murmu et al., 2013). Furthermore, higher prices of organically produced vegetable products than conventional products in the fresh markets encourage farmers to grow vegetables organically. Moreover, the organically grown products are safer to eat and are more nutritious than products grown conventionally (Ramesh et al., 2005; Lester, 2006). Organic amendments are most common in vegetable crop fields through the application of composted materials or recycled crop wastes (Murmu et al., 2013; Ahirwar \& Hussain, 2015). The use of recycled crop waste as organic fertilizer or soil amendment material not only provides an economic advantage to small-scale farmers, but also reduces soil pollution due to reduced use of synthetic fertilizers, pesticides, nutrient run-off, and nitrogen (N) leaching (Nyamangara et al., 2003; Liu et al. 2013; Abafita et al., 2014). Many of agricultural areas in Saudi Arabia generate large quantities of organic residues such as date palm, olive, and maize wastes, as well as fruit and vegetable processing remains. Recycling of these organic agricultural wastes has great potential to serve as sources of mulch, nutrients and organic material to enhance agricultural production and sustainability (Alburquerque et al., 2006; Altieri \& Esposito, 2008; Rigane \&Medhioub, 2011; Killi \& Kavdir, 2013).

Thus, Application of these composted materials to soil not only enhances soil organic matter and soil fertility levels but also increases microbial activity (Zayed \& Abdel-Motaalet, 2005; Benito et al., 2006; Liu et al., 2013; Khan et al., 2017). Improved soil fertility and microbial activity as a result of returned such crop wastes as compost improves the condition of agricultural soil and increases root vigor and other physiological characteristics of plants such as photosynthetic rate and chlorophyll and carbohydrate content (Joshi et al., 2009; Yogev et al., 2009).

On the other hand, the use of organic fertilizer with nitrogen, phosphorus and potassium fertilizers were found more valuable for maximizing yield and providing macronutrients in tomato (Khan et al., 2017). Khan et al. (2017) reported that single source of nutrients like mineral fertilizers, composts or animal manures cannot meet the nutrient demands of the crops for sustainable production; therefore, a proper ratio of organic and inorganic fertilizers is important for higher crop production. Many investigations indicated that composted crop wastes show beneficial effects on plant growth, yield and quality of tomato (Pane et al., 2015; Khan et al., 2017; Wang et al., 2017). However, there have been little experimental studies exploring influences of composted crop wastes in combination with either mineral fertilizers or manures on tomato. Therefore, the main objective of this study was to assess the influence of application of crop waste compost consisting of date palm, olive and maize wastes amended with different rates of sheep manure and NPK fertilizer on the growth, chlorophyll and mineral concentrations, yield and its components, and fruit quality of tomato under field conditions.

\section{Materials and Methods}

\subsection{Experimental Setup}

Two field experiments were conducted at El-Watania Farm located in El-Jouf region, Saudi Arabia during two successive growing seasons of 2013 and 2014. The treatment plan comprised five mixtures of composted agricultural crop wastes enriched with NPK mineral actives and different rates of sheep manure as follows:

$\mathrm{C} 1=(1$ date palm : 1 olive $: 1$ maize $)$ waste + mineral actives (mixed NPK), this treatment considered as a control.

$\mathrm{C} 2=(1$ date palm : 1 olive $: 1$ maize $)$ waste $+5 \%$ sheep manure

$\mathrm{C} 3=(1$ date palm $: 1$ olive $: 1$ maize $)$ waste $+10 \%$ sheep manure

$\mathrm{C} 4=(1$ date palm : 1 olive $: 1$ maize $)$ waste $+20 \%$ sheep manure

$\mathrm{C} 5=(1$ date palm $: 1$ olive $: 1$ maize $)$ waste $+40 \%$ sheep manure

The mineral actives consisted of a mineral fertilizer mixture of 20 $\mathrm{kg} \mathrm{N}$ as ammonium sulfate $+7 \mathrm{~kg}_{2} \mathrm{O}_{5}$ as super phosphate +1.25 $\mathrm{kg} \mathrm{K}_{2} \mathrm{O}$ as potassium sulfate, added to a ton of agricultural crop wastes (crushed date palm + crushed olive trees + crushed maize plants, at a ratio of 1:1:1) (AL-Kahtani \& Ahmed, 2012). Before starting the experiment, mechanical and chemical analyses of both soil and different organic compost mixtures carried out by following Chapman \& Pratt (1978) procedures (Table 1). Five compost materials were applied @ $30 \mathrm{~kg}$ for each plot (25 plants) 
Table 1: Chemical properties of the soil and mixtures of plant residues plus sheep manure composts

\begin{tabular}{|ccccccccccccccc|} 
Properties & $\mathrm{pH}$ & $\begin{array}{c}\mathrm{EC} \\
\left.(\mathrm{dS} \mathrm{m})^{-1}\right)\end{array}$ & $\begin{array}{c}\mathrm{OM} \\
(\%)\end{array}$ & Total $\mathrm{N}(\%)$ & $\begin{array}{c}\text { Total } \\
\mathrm{P}(\%)\end{array}$ & $\begin{array}{c}\text { Total } \\
\mathrm{K}(\%)\end{array}$ & $\begin{array}{c}\mathrm{Fe} \\
(\mathrm{ppm})\end{array}$ & $\mathrm{Mn}(\mathrm{ppm})$ & $\begin{array}{c}\mathrm{Zn} \\
(\mathrm{ppm})\end{array}$ & $\begin{array}{c}\mathrm{Co} \\
(\mathrm{ppm})\end{array}$ & $\begin{array}{c}\mathrm{Pb} \\
(\mathrm{ppm})\end{array}$ & $\begin{array}{c}\mathrm{C} / \mathrm{N} \\
\mathrm{ratio}\end{array}$ & $\begin{array}{c}\mathrm{Cubic} \text { meter } \\
\text { weight }(\mathrm{Kg})\end{array}$ \\
\hline Soil & 7.98 & 0.540 & 0.965 & 0.07 & 0.116 & 0.087 & 4.88 & 0.47 & 0.62 & 0.13 & Trace & - & - \\
\hline $\mathrm{C} 1$ & 7.52 & 3.48 & 24.78 & 1.60 & 0.518 & 0.322 & 6425 & 75 & 28 & 25 & 12 & 9 & 601 \\
\hline $\mathrm{C} 2$ & 7.32 & 3.59 & 22.93 & 1.60 & 0.532 & 0.318 & 7156 & 101 & 32 & 24 & 5 & 8 & 559 \\
\hline $\mathrm{C} 3$ & 7.31 & 3.61 & 22.13 & 1.84 & 0.525 & 0.337 & 7936 & 109 & 32 & 28 & 5 & 7 & 546 \\
\hline $\mathrm{C} 4$ & 7.15 & 3.86 & 24.58 & 1.88 & 0.602 & 0.398 & 8130 & 122 & 42 & 30 & 5 & 8 & 533 \\
\hline $\mathrm{C} 5$ & 7.11 & 4.20 & 28.92 & 1.92 & 0.639 & 0.417 & 8994 & 137 & 57 & 35 & 6 & 9 & 557 \\
\hline
\end{tabular}

through incorporating them into the soil three days before transplanting. Normal cultural practices such as irrigation, weeding, insect, and disease control performed appropriately.

Present study was conducted on tomato (Solanum lycopersicum Mill. 'Asala') plants grown in sandy soil under drip irrigation system. Seeds of Asala $F_{1}$ tomato (Rizk Zwaan, The Netherlands) were sown on March 1 $1^{\text {st }}, 2013$ and 2014 in seedling trays and placed in the greenhouse. Thirty-day-old regular and healthy seedlings were transplanted into $15 \mathrm{~m}^{2}$ plots. Seedlings were transplanted in one long row (25 plants per row) at $1.0 \mathrm{~m}$ distance between rows and $0.5 \mathrm{~m}$ distance within rows.

The experimental lay out consisted of randomized complete blocks and five compost treatments with five replicates each. Each block had a separate furrow $(1 \mathrm{~m})$ between each compost treatment. The block size was $10 \mathrm{~m}$ long, and each block included 25 plants, of which 10 center plants were selected for determination of the growth, yield, and fruit quality characteristics.

\subsection{Data measurements}

\subsubsection{Vegetative growth}

Plant height (from soil surface up to the top of the canopy) was measured twice, 30 and 60 days after transplanting. At harvest, 15 whole plants per plot (three plants per replicate) were collected, oven-dried at $70^{\circ} \mathrm{C}$ until constant weight, and then analyzed to determine shoot dry mass.

\subsubsection{Total Leaf chlorophyll content}

Total leaf Chlorophyll was measurements on four of the youngest fully expanded leaves of five different plants. Fresh leaf extract $(0.03 \mathrm{~g})$ from each compost treatment were extracted using $5 \mathrm{ml} \mathrm{N}$ dimethyl formamide, following which chlorophyll $\mathrm{a}, \mathrm{b}$, and total chlorophyll content was assessed calorimetrically at wave length of 663.8 and $646.8 \mathrm{~nm}$, respectively (AL-Kahtani \& Ahmed,
2012). The concentration of each constituent was calculated as follows (Porra et al., 1989):

Chlorophyll a $=13.43 \times$ A $663.8-3.47 \times$ A $646.8\left(\mathrm{~nm} \mathrm{ml}^{-1}\right)$

Chlorophyll b $=22.9 \times$ A $646.8-5.38 \times A 663.8\left(\mathrm{~nm} \mathrm{ml}^{-1}\right)$

Total Chlorophyll $=19.43 \times$ A $646.8+8.05 \times$ A $663.8\left(\mathrm{~nm} \mathrm{ml}^{-1}\right)$

\subsubsection{Leaf mineral content}

At mid-flowering stage, the four fully expanded leaf samples were collected randomly from four plants in each plot, washed once with normal tap water and twice with distilled water, then oven dried at $70^{\circ} \mathrm{C}$ and ground to a fine powder with a Willey-mill for determination of mineral content. The dry samples were homogenized and analyzed for nitrogen $(\mathrm{N})$, phosphorous $(\mathrm{P})$, potassium $(\mathrm{K})$, ferrous $(\mathrm{Fe})$, manganese $(\mathrm{Mn})$, zinc $(\mathrm{Zn})$, nickel $(\mathrm{Ni})$, lead $(\mathrm{Pb})$, cobalt $(\mathrm{Co})$, and cadmium $(\mathrm{Cd})$ concentrations. Among this $\mathrm{N}$ was determined using the Micro-Kjeldahl method (Jackson, 1973), while leaf $\mathrm{P}$ was determined by using the vanadomolybdophosphoric method (Kacar \& Intal 2008). Further, $\mathrm{K}, \mathrm{Fe}, \mathrm{Zn}$, and $\mathrm{Mn}$ were estimated through dry-ashing leaves at $500^{\circ} \mathrm{C}$, digestion, and atomic absorption spectrophotometery (Perkin-Elmer 214, Norwalk, CT, USA) as described by Jones (1977). Heavy metals ( $\mathrm{Ni}, \mathrm{Pb}, \mathrm{Co}$, and $\mathrm{Cd}$ ) concentrations were determined using atomic absorption (Optical Emission Spectrometer Model, Optima 4300 DV, USA).

\subsubsection{Yield and fruit characteristics}

Fruits of tomato were harvested twice a week at firm red-ripe stage. Total yield was recorded as total fruit weight per plant $(\mathrm{kg}$ plant $\left.^{-1}\right)$ and per plot $\left(\mathrm{t} \mathrm{ha}^{-1}\right)$. Twenty fruits per plot were randomly picked and separated into two groups for determining fruit characteristics such as weight $(\mathrm{g})$, length and diameter $(\mathrm{cm})$, volume $\left(\mathrm{cm}^{3}\right)$, and fruit quality. Fruit weight was detected using ten randomly selected marketable fruits. Fruit length and diameter were measured on the same ten randomly selected fruits using 
Calipers (Etissa et al., 2014). Fruit size $\left(\mathrm{cm}^{3}\right)$ was determined by other ten randomly selected sample fruits and their volume was registered using the displacement of water $(\mathrm{ml})\left(1 \mathrm{ml}=1 \mathrm{~cm}^{3}\right)$ and calculating their average (Khan et al., 2014).

\subsubsection{Fruit quality characteristics}

The previous ten sample of fruits were used for assessment of fruit quality characteristics. Fruits were cut into small pieces, then a volume $(\mathrm{ml})$ of tomato juice was extracted from these 10 sample fruits using a juice extractor (Type 6001x, USA) and clear juice was used for quality analyses. Juice volume measured in a graduated cylinder after removing the seeds, skins, and pulps (Etissa et al., 2014). Ascorbic acid content (vitamin C (VC), mg $100 \mathrm{~g}^{-1} \mathrm{FW}$ ) was determined in tomato juice by using the 2,6dichloroindophenol titrimetric method (AOAC, 2000). Total soluble solids (TSS, \% Brix) was determined by placing one to two drops of clear juice on the prism of a digital refractometer (PR-101, ATAGO, Japan). Titratable acidity (TA, \%) of tomato juice was measured using $10 \mathrm{ml}$ of filtrate juice and supplied for titration using $0.1 \mathrm{~N} \mathrm{NaOH}$ until $\mathrm{pH} 8.2$, and expressed as citric acid percentage (Turhan \& Seniz, 2009). The $\mathrm{pH}$ of tomato fruit juice was determined in a $50 \mathrm{ml}$ filtrate juice attained from a mixture of $10 \mathrm{~g}$ of fruits flesh tissues blended in $100 \mathrm{ml}$ of deionized water (Polat et al., 2010).

\subsection{Statistical Analysis:}

The procedures of Snedecor \& Cochran (1980) were used for statistical analysis of the data, and means were separated using Duncan's multiple range tests.

\section{Results and Discussion}

\subsection{Plant growth and development}

For 'Asala' tomato plant height after 30 and 60 days from transplanting, significant responses to the five compost types were observed (Table 2). A significant increase in plant height was observed for compost type enriched by a higher rate of sheep manure (C5) followed by (C4) treatment. However, the shortest plant was detected in compost type enriched with only mineral NPK fertilizer (C1, control treatment) (Table 2). These results may relate to the suitable physicochemical status of palm waste that was influenced by supplementation of both water and nutrient elements for growing plants (Ghehsareh \& Kalbasi, 2012). Shoot dry mass was significantly increased by increasing application rate of sheep manure in the compost (Table 2). Maximum shoot dry mass was recorded in the $\mathrm{C} 5$ treatment followed by $\mathrm{C} 4$ treatment in both years. Higher shoot dry mass might indicate that the total uptake of nutrients was more efficiency under $\mathrm{C} 4$ and $\mathrm{C} 5$ treatments. Shoot dry mass of the C5 treatment was 13.53-20.33\% higher than that of the $\mathrm{C} 1$ (control treatment). This result was in

Table 2: Influence of compost type on plant growth and leaf chlorophyll content of Asala variety of tomato during two seasons of 2013 and 2014

\begin{tabular}{|c|c|c|c|c|c|c|}
\hline \multirow{2}{*}{$\begin{array}{l}\text { Experimental } \\
\text { treatments }\end{array}$} & \multicolumn{2}{|c|}{ Plant height $(\mathrm{cm})$} & \multirow{2}{*}{$\begin{array}{l}\text { Shoot dry } \\
\text { mass (\%) }\end{array}$} & \multicolumn{3}{|c|}{ Leaf chlorophyll content $\left(\mathrm{nm} \mathrm{ml}^{-1}\right)$} \\
\hline & 30 days & 60 days & & Chlorophyll a & Chlorophyll b & Total chlorophyll \\
\hline \multicolumn{7}{|c|}{ First season (2013) } \\
\hline $\mathrm{C} 1$ & $25.53^{\mathrm{e}}$ & $46.57^{\mathrm{d}}$ & $22.14^{\mathrm{b}}$ & $6.33^{\mathrm{d}}$ & $1.33^{\mathrm{b}}$ & $7.66^{\mathrm{d}}$ \\
\hline $\mathrm{C} 2$ & $27.40^{\mathrm{d}}$ & $47.77^{\mathrm{d}}$ & $24.14^{\mathrm{ab}}$ & $8.14^{\mathrm{c}}$ & $1.45^{\mathrm{b}}$ & $9.59^{\mathrm{c}}$ \\
\hline $\mathrm{C} 3$ & $28.33^{\mathrm{c}}$ & $50.77^{\mathrm{c}}$ & $24.45^{\mathrm{ab}}$ & $9.37^{\mathrm{b}}$ & $1.54^{\mathrm{b}}$ & $10.91^{\mathrm{bc}}$ \\
\hline $\mathrm{C} 4$ & $29.33^{\mathrm{b}}$ & $52.77^{\mathrm{b}}$ & $25.80^{\mathrm{a}}$ & $9.55^{\mathrm{b}}$ & $1.89^{\mathrm{b}}$ & $11.44^{\mathrm{b}}$ \\
\hline $\mathrm{C} 5$ & $31.33^{\mathrm{a}}$ & $55.90^{\mathrm{a}}$ & $26.64^{\mathrm{a}}$ & $11.30^{\mathrm{a}}$ & $2.73^{\mathrm{a}}$ & $14.03^{\mathrm{a}}$ \\
\hline \multicolumn{7}{|c|}{ Second season (2014) } \\
\hline $\mathrm{C} 1$ & $23.70^{\mathrm{d}}$ & $42.83^{\mathrm{e}}$ & $21.87^{\mathrm{b}}$ & $7.39^{\mathrm{c}}$ & $2.18^{\mathrm{b}}$ & $9.57^{\mathrm{d}}$ \\
\hline $\mathrm{C} 2$ & $25.10^{\mathrm{c}}$ & $44.60^{\mathrm{d}}$ & $22.87^{\mathrm{ab}}$ & $7.89^{\mathrm{bc}}$ & $2.43^{\mathrm{b}}$ & $10.32^{\text {cd }}$ \\
\hline $\mathrm{C} 3$ & $26.33^{\mathrm{b}}$ & $46.27^{\mathrm{c}}$ & $23.33^{\mathrm{ab}}$ & $8.37^{\mathrm{b}}$ & $2.62^{\mathrm{b}}$ & $10.99^{\mathrm{bc}}$ \\
\hline $\mathrm{C} 4$ & $27.30^{\mathrm{b}}$ & $48.50^{\mathrm{b}}$ & $24.17^{\mathrm{a}}$ & $8.48^{\mathrm{b}}$ & $2.92^{\mathrm{b}}$ & $11.40^{\mathrm{b}}$ \\
\hline $\mathrm{C} 5$ & $29.70^{\mathrm{a}}$ & $51.60^{\mathrm{a}}$ & $24.83^{\mathrm{a}}$ & $9.79^{\mathrm{a}}$ & $3.14^{\mathrm{a}}$ & $12.93^{\mathrm{a}}$ \\
\hline
\end{tabular}

Within each column, mean values with same letters are not significantly different at $5 \%$ level of significance. 
agreement with that of Azarmi et al. (2008), those who reported that shoot dry weight of tomato plants grown in plots amended with $15 \mathrm{t} \mathrm{ha}^{-1}$ of sheep-manure vermicompost was $27 \%$ greater than that of the control plants. On the contrary, compost enriched with mineral NPK fertilizer (C1) generated the lowest reduction in shoot dry mass (Table 2). The application of agricultural waste compost incorporated with sheep manure may increase the soil microbial activity and nutrient availability which resulting in more nutrient uptake ultimately improved the growth of tomato (Khan et al., 2017).

\subsection{Leaf chlorophyll content}

The influence of compost types on leaf chlorophyll content was significant (Table 2). The highest and lowest significant values of leaf chlorophyll a, chlorophyll $\mathrm{b}$, and total chlorophyll content were observed in $\mathrm{C} 5$ and $\mathrm{C} 1$ plants, respectively, but there were no significant variations in chlorophyll content between $\mathrm{C} 3$ and C4 plants, though they also revealed higher chlorophyll content than that of $\mathrm{C} 1$ plants. Superior effects of the C5 type on chlorophyll content might be attributing to the fact that this compost type performed the best as a source of $\mathrm{N}$ (Table 1). This result could be due to the higher $\mathrm{N}$ content in the soil resulted from applying agricultural waste compost and $40 \%$ sheep manure. Where, the level of $\mathrm{N}$ available for plant growth within growing media often linked to chlorophyll content (Shadchina \& Dmitrieva, 1995; Killi \& Kavdir, 2013). Besides, organic acids and carbon dioxide derived from organic manure degradation play a role in enhancing the availability of some nutrients such as magnesium $(\mathrm{Mg})$, which is involved in chlorophyll synthesis and in turn increases the photosynthesis rate (Gulshan et al., 2013).

\subsection{Leaf mineral concentrations}

Mineral concentration of $\mathrm{N}, \mathrm{P}, \mathrm{K}, \mathrm{Fe}, \mathrm{Zn}$ and $\mathrm{Mn}$ in tomato leaf tissues were significantly affected by compost mixture (Table 3 ). Increasing sheep manure rates in mixed compost increased most of the mineral concentrations. In case of $\mathrm{P}$ and $\mathrm{K}$ concentrations, result of the present study are in accordance with the findings of Jordao et al. (2006) and Azarmi et al. (2008), those who reported that sheep-manure vermicompost enhanced $\mathrm{P}$ and $\mathrm{K}$ concentrations and uptake in soil through increasing the solubilization of $\mathrm{P}$ and $\mathrm{K}$ by the activation of microorganisms with the release of several organic acids that improve the availability of soluble $\mathrm{P}$ and $\mathrm{K}$ in soil. Applied compost with higher rates of sheep manure significantly increased $\mathrm{N}, \mathrm{Fe}, \mathrm{Zn}$, and $\mathrm{Mn}$ concentrations in tomato leaves, particularly in comparison with compost enriched with NPK (C1). Similar results were obtained by Azarmi et al. (2008) who reported that increasing sheep-manure vermicompost application rate into the soil resulted in significantly increased $\mathrm{Fe}$ and $\mathrm{Zn}$ content in tomato shoots in plots treated with 15 and $10 \mathrm{t} \mathrm{ha}^{-1}$ of sheepmanure vermicompost, respectively than tomato shoots in control plots. Conversely, insignificant differences were reported in case

Table 3: Influence of compost type on leaf mineral concentrations of Asala variety of tomato during two seasons of 2013 and 2014

\begin{tabular}{|ccccccccccc|}
\hline $\begin{array}{c}\text { Experimental } \\
\text { treatments }\end{array}$ & $\begin{array}{c}\mathrm{N} \\
(\%)\end{array}$ & $\begin{array}{c}\mathrm{P} \\
(\%)\end{array}$ & $\begin{array}{c}\mathrm{K} \\
(\%)\end{array}$ & $\begin{array}{c}\mathrm{Fe} \\
(\mathrm{ppm})\end{array}$ & $\begin{array}{c}\mathrm{Zn} \\
(\mathrm{ppm})\end{array}$ & $\begin{array}{c}\mathrm{Mn} \\
(\mathrm{ppm})\end{array}$ & $\begin{array}{c}\mathrm{Ni} \\
(\mathrm{ppm})\end{array}$ & $\begin{array}{c}\mathrm{Pb} \\
(\mathrm{ppm})\end{array}$ & $\begin{array}{c}\mathrm{Co} \\
(\mathrm{ppm})\end{array}$ & $\begin{array}{c}\mathrm{Cd} \\
(\mathrm{ppm})\end{array}$ \\
\hline $\mathrm{C} 1$ & $3.57^{\mathrm{d}}$ & $0.30^{\mathrm{b}}$ & $3.40^{\mathrm{d}}$ & $546.0^{\mathrm{d}}$ & $36.9^{\mathrm{c}}$ & $33.6^{\mathrm{c}}$ & $0.57^{\mathrm{a}}$ & $\mathrm{UDL}$ & $\mathrm{UDL}$ & $\mathrm{UDL}$ \\
\hline $\mathrm{C} 2$ & $3.57^{\mathrm{d}}$ & $0.37^{\mathrm{ab}}$ & $3.60^{\mathrm{d}}$ & $688.3^{\mathrm{c}}$ & $39.8^{\mathrm{bc}}$ & $49.8^{\mathrm{b}}$ & $0.32^{\mathrm{a}}$ & $\mathrm{UDL}$ & $\mathrm{UDL}$ & $\mathrm{UDL}$ \\
\hline $\mathrm{C} 3$ & $3.77^{\mathrm{c}}$ & $0.37^{\mathrm{ab}}$ & $3.93^{\mathrm{c}}$ & $967.1^{\mathrm{b}}$ & $42.7^{\mathrm{b}}$ & $48.1^{\mathrm{b}}$ & $0.20^{\mathrm{a}}$ & $\mathrm{UDL}$ & UDL & UDL \\
\hline $\mathrm{C} 4$ & $3.93^{\mathrm{b}}$ & $0.40^{\mathrm{a}}$ & $4.27^{\mathrm{b}}$ & $965.9^{\mathrm{b}}$ & $42.3^{\mathrm{b}}$ & $51.9^{\mathrm{b}}$ & $0.73^{\mathrm{a}}$ & UDL & UDL & UDL \\
\hline $\mathrm{C} 5$ & $4.20^{\mathrm{a}}$ & $0.43^{\mathrm{a}}$ & $4.73^{\mathrm{a}}$ & $1069.6^{\mathrm{a}}$ & $50.9^{\mathrm{a}}$ & $57.6^{\mathrm{a}}$ & $0.33^{\mathrm{a}}$ & UDL & UDL & UDL \\
\hline $\mathrm{C} 1$ & $2.90^{\mathrm{d}}$ & $0.30^{\mathrm{c}}$ & $3.20^{\mathrm{d}}$ & $308.6^{\mathrm{c}}$ & $29.20^{\mathrm{c}}$ & $24.03^{\mathrm{d}}$ & $0.77^{\mathrm{a}}$ & UDL & UDL & UDL \\
\hline $\mathrm{C} 2$ & $3.13^{\mathrm{c}}$ & $0.30^{\mathrm{c}}$ & $3.37^{\mathrm{c}}$ & $349.5^{\mathrm{d}}$ & $30.43^{\mathrm{c}}$ & $25.70^{\mathrm{c}}$ & $0.80^{\mathrm{a}}$ & UDL & UDL & UDL \\
\hline $\mathrm{C} 3$ & $3.23^{\mathrm{bc}}$ & $0.33^{\mathrm{bc}}$ & $3.47^{\mathrm{c}}$ & $375.8^{\mathrm{c}}$ & $34.00^{\mathrm{b}}$ & $26.77^{\mathrm{c}}$ & $0.17^{\mathrm{a}}$ & UDL & UDL & UDL \\
\hline $\mathrm{C} 4$ & $3.30^{\mathrm{b}}$ & $0.37^{\mathrm{ab}}$ & $3.60^{\mathrm{b}}$ & $400.5^{\mathrm{b}}$ & $36.03^{\mathrm{b}}$ & $28.30^{\mathrm{b}}$ & $0.97^{\mathrm{a}}$ & UDL & UDL & UDL \\
\hline $\mathrm{C} 5$ & $3.50^{\mathrm{a}}$ & $0.40^{\mathrm{a}}$ & $3.90^{\mathrm{a}}$ & $449.2^{\mathrm{a}}$ & $41.90^{\mathrm{a}}$ & $31.10^{\mathrm{a}}$ & $0.80^{\mathrm{a}}$ & UDL & UDL & UDL \\
\hline
\end{tabular}

Means with the same letter within each column are not significantly different at 5\% level of significance, UDL: Under the Detection Limit 
of $\mathrm{Ni}$ content of tomato leaves grown in plots amended with different types of compost treatments, mainly in the first and second seasons. On the other hand, not all compost treatments resulted into higher heavy metal concentrations, i.e., concentrations of $\mathrm{Pb}, \mathrm{Co}$, and $\mathrm{Cd}$ in leaf tissues were under the detection limit (Table 3). These results agree with the findings of Elouear et al. (2016) those who reported that alfalfa plants grown in the soil treated with sheep manure showed significantly lower concentrations of $\mathrm{Pb}$ and $\mathrm{Cd}$ compared to the control.

\subsection{Total yield and fruit characteristics}

Plots applied with compost enriched with a higher rate of sheep manure (C5) produced the highest fruit weight, fruit volume, and consequently total fruit yield (plant ${ }^{-1}$ and $\mathrm{t} \mathrm{ha}^{-1}$ ), while compost enriched with NPK fertilizer ( $\mathrm{C} 1$, control treatment) gave the lowest values of total yield and its components (Table 4). For average fruit weight and fruit volume, the use of C5 resulted in the highest values of 192.9-225.6 $\mathrm{g}$ and 188.3-222.3 $\mathrm{cm}^{3}$, respectively, in comparison with $\mathrm{C} 1$ (109.7-149.2 $\mathrm{g}$ and 110.0$150.0 \mathrm{~cm}^{3}$, respectively). On the other hand, percentage increase in total fruit yield (plant ${ }^{-1}$ and $\mathrm{t} \mathrm{ha}^{-1}$ ) of plants fertilized with $\mathrm{C5}$ was $65.71-65.83 \%$ higher than that of plants nourished with compost + NPK (C1). The marked effect of C5 type on tomato fruit yield might be due to the cumulative stimulating influence of $\mathrm{N}$ on plant height and shoot dry mass traits (Table 2), which represent the foundation for flowering and fruit formation. In general, all compost treatments supplemented with different rates of sheep manure resulted in significantly higher yield and its components than compost supplemented with mineral NPK fertilizer. However, total yield and fruit weight and volume characteristics significantly varied among the compost types with an increase order of $\mathrm{C} 5>\mathrm{C} 4>\mathrm{C} 3>\mathrm{C} 2>\mathrm{C} 1$ (Table 4). These results support the results observed by Parbha et al. (2007) who reported that increases in plant growth and yield of tomato with addition of sheep-manure vermicompost were associated with greater uptake of elements, mainly $\mathrm{P}, \mathrm{K}, \mathrm{Fe}$, and Zn. Moreover, compost types enriched with different rates of sheep manure (C2 to C5) significantly increased fruit length and diameter compared with compost enriched with NPK (C1) (Table 4). High yield and nutrient concentrations of tomato plants nourished with compost supplemented with sheep manure could be because such substances not only contained sufficient nutrients, but also because the nutrients were slowly released to the plants. This avoids nutrient loss and leaching, improving nutrient use efficiency (Ilupeju et al., 2015). Moreover, the use of organic fertilizer led to increase soil organic carbon and soil fertility, consequently resulting in a larger yield trend in comparison with a balanced chemical fertilizer (Wang et al., 2017).

\subsection{Fruit quality aspects}

The results presented in Table 5 shows that VC, TSS, TA, pH, and fruit juice $(\%)$ of tomato were also influenced by different

Table 4 Influence of compost type on total yield and some fruit characteristics of Asala tomato variety during two seasons of 2013 and 2014

\begin{tabular}{|c|c|c|c|c|c|c|}
\hline \multirow{2}{*}{$\begin{array}{l}\text { Experimental } \\
\text { treatments }\end{array}$} & \multicolumn{2}{|c|}{ Total yield } & \multirow{2}{*}{$\begin{array}{l}\text { Fruit weight } \\
\qquad(\mathrm{g})\end{array}$} & \multirow{2}{*}{$\begin{array}{l}\text { Fruit volume } \\
\qquad\left(\mathrm{cm}^{3}\right)\end{array}$} & \multirow{2}{*}{$\begin{array}{l}\text { Fruit length } \\
\quad(\mathrm{cm})\end{array}$} & \multirow{2}{*}{$\begin{array}{l}\text { Fruit diameter } \\
\qquad(\mathrm{cm})\end{array}$} \\
\hline & $\left(\mathrm{kg}\right.$ plant $\left.^{-1}\right)$ & $\left(\mathrm{tha}^{-1}\right)$ & & & & \\
\hline \multicolumn{7}{|c|}{ First season (2013) } \\
\hline $\mathrm{C} 1$ & $3.50^{\mathrm{e}}$ & $87.5^{\mathrm{d}}$ & $149.2^{\mathrm{e}}$ & $150.0^{\mathrm{d}}$ & $5.41^{\mathrm{b}}$ & $6.42^{\mathrm{c}}$ \\
\hline $\mathrm{C} 2$ & $3.85^{\mathrm{d}}$ & $96.3^{\mathrm{c}}$ & $172.9^{\mathrm{d}}$ & $176.7^{\mathrm{c}}$ & $5.93^{\mathrm{ab}}$ & $6.94^{\mathrm{b}}$ \\
\hline $\mathrm{C} 3$ & $4.39^{\mathrm{c}}$ & $109.8^{\mathrm{b}}$ & $183.1_{\mathrm{c}}$ & $191.7^{\mathrm{b}}$ & $6.07^{\mathrm{a}}$ & $7.07^{\mathrm{ab}}$ \\
\hline $\mathrm{C} 4$ & $4.62^{\mathrm{b}}$ & $115.5^{\mathrm{b}}$ & $195.1^{\mathrm{b}}$ & $200.0^{\mathrm{b}}$ & $6.31^{\mathrm{a}}$ & $7.17^{\mathrm{ab}}$ \\
\hline $\mathrm{C} 5$ & $5.80^{\mathrm{a}}$ & $145.0^{\mathrm{a}}$ & $225.6^{\mathrm{a}}$ & $222.3^{\mathrm{a}}$ & $6.40^{\mathrm{a}}$ & $7.34^{\mathrm{a}}$ \\
\hline \multicolumn{7}{|c|}{ Second season (2014) } \\
\hline $\mathrm{C} 1$ & $3.22^{\mathrm{d}}$ & $80.5^{\mathrm{d}}$ & $109.7^{\mathrm{d}}$ & $110.0^{\mathrm{d}}$ & $5.43^{\mathrm{c}}$ & $6.20^{\mathrm{c}}$ \\
\hline $\mathrm{C} 2$ & $3.46^{\mathrm{c}}$ & $86.5^{\mathrm{c}}$ & $137.8^{\mathrm{c}}$ & $135.0^{\mathrm{c}}$ & $5.93^{\mathrm{b}}$ & $6.67^{\mathrm{b}}$ \\
\hline $\mathrm{C} 3$ & $4.21^{\mathrm{b}}$ & $105.3^{\mathrm{b}}$ & $157.4^{\mathrm{b}}$ & $158.3^{\mathrm{b}}$ & $5.99^{\mathrm{b}}$ & $6.90^{\mathrm{b}}$ \\
\hline $\mathrm{C} 4$ & $4.24^{\mathrm{b}}$ & $106.0^{\mathrm{b}}$ & $164.6^{\mathrm{b}}$ & $165.0^{\mathrm{b}}$ & $6.10^{\mathrm{ab}}$ & $6.93^{\mathrm{ab}}$ \\
\hline C5 & $5.34^{\mathrm{a}}$ & $133.5^{\mathrm{a}}$ & $192.9^{\mathrm{a}}$ & $188.3^{\mathrm{a}}$ & $6.43^{\mathrm{a}}$ & $7.27^{\mathrm{a}}$ \\
\hline
\end{tabular}

Means with the same letter within a column are not significantly different at $5 \%$ level of significance 
Table 5 Influence of compost type on fruit quality characteristics of Asala tomato variety during two seasons of 2013 and 2014

\begin{tabular}{|c|c|c|c|c|c|c|c|c|c|c|}
\hline \multirow[t]{2}{*}{ Treatments } & \multicolumn{2}{|c|}{$\begin{array}{l}\text { Fruit juice } \\
\quad(\mathrm{ml})\end{array}$} & \multicolumn{2}{|c|}{$\begin{array}{c}\mathrm{VC} \\
\text { (mg/100 ml Juice) }\end{array}$} & \multicolumn{2}{|c|}{$\begin{array}{l}\text { TSS } \\
(\%)\end{array}$} & \multicolumn{2}{|c|}{$\begin{array}{l}\text { TA } \\
(\%)\end{array}$} & \multicolumn{2}{|c|}{$\mathrm{pH}$} \\
\hline & 2013 & 2014 & 2013 & 2014 & 2013 & 2014 & 2013 & 2014 & 2013 & 2014 \\
\hline $\mathrm{C} 1$ & $41.5^{\mathrm{c}}$ & $36.65^{\mathrm{b}}$ & $23.33^{\mathrm{c}}$ & $24.14^{\mathrm{c}}$ & $4.60^{\mathrm{d}}$ & $4.03^{\mathrm{d}}$ & $0.56^{\mathrm{a}}$ & $0.45^{\mathrm{a}}$ & $4.89^{\mathrm{a}}$ & $4.74^{\mathrm{a}}$ \\
\hline $\mathrm{C} 2$ & $48.7^{\mathrm{ab}}$ & $39.45^{\mathrm{b}}$ & $31.31^{\mathrm{b}}$ & $26.50^{\mathrm{b}}$ & $5.30^{\mathrm{b}}$ & $4.60^{\mathrm{c}}$ & $0.40^{\mathrm{b}}$ & $0.38^{\mathrm{b}}$ & $4.62^{\mathrm{b}}$ & $4.51^{\mathrm{b}}$ \\
\hline $\mathrm{C} 3$ & $45.8^{\mathrm{b}}$ & $44.13^{\mathrm{a}}$ & $33.33^{\mathrm{b}}$ & $26.51^{\mathrm{b}}$ & $5.10^{c}$ & $4.63^{\mathrm{c}}$ & $0.34^{\mathrm{cd}}$ & $0.37^{\mathrm{b}}$ & $4.33^{\mathrm{b}}$ & $4.45^{\mathrm{b}}$ \\
\hline $\mathrm{C} 4$ & $49.5^{\mathrm{ab}}$ & $45.65^{\mathrm{a}}$ & $33.33^{b}$ & $28.03^{\mathrm{ab}}$ & $5.07^{\mathrm{c}}$ & $5.13^{\mathrm{b}}$ & $0.36^{\mathrm{c}}$ & $0.32^{\mathrm{c}}$ & $4.17^{\mathrm{c}}$ & $4.38^{\mathrm{b}}$ \\
\hline $\mathrm{C} 5$ & $51.6^{\mathrm{a}}$ & $48.02^{\mathrm{a}}$ & $37.38^{\mathrm{a}}$ & $29.72^{\mathrm{a}}$ & $5.80^{\mathrm{a}}$ & $5.83^{\mathrm{a}}$ & $0.32^{\mathrm{d}}$ & $0.30^{\mathrm{c}}$ & $4.04^{\mathrm{d}}$ & $4.19^{c}$ \\
\hline
\end{tabular}

Mean s with the same letter within a column are not significantly different at $5 \%$ level of significance

combinations of composts. Tomato fruit quality of $\mathrm{C} 5$ treatment had the highest significant VC and TSS content than any of the compost types. Improvement of tomato fruit quality under C5 treatment attributed to the better growth of plants (Table 2), which might have favored the production of quality fruits. However, Compost amended with NPK (C1) exhibited higher values of TA and $\mathrm{pH}$ of fruit juice in comparison with all the other composts amended with different rates of sheep manure. These findings are in accordance with those of Youssef \& Eissa (2016). Fruit pH is an important factor for fresh consumption tomato; low $\mathrm{pH}$ improves taste and flavor of the fruit (Eivazi et al., 2013). All compost types had $\mathrm{pH}$ values ranging from 4.04 to 4.89 . These values are relatively similar to those reported by various researchers in previously conducted studies (Eivazi et al., 2013; Dabire et al., 2016; Youssef \& Eissa, 2016). They detected pH values ranging from 4.19 to 4.45 in many tomato varieties grown in soil amended with different mineral and organic fertilizers. The TA values recorded in this study ranged from 0.30 to $0.56 \%$. The highest value of TA $(0.45-0.56 \%)$ was observed under $\mathrm{C} 1$ compost, while the lowest TA value $(0.30-0.32 \%)$ was observed under C5 compost. This result are in disagreement with the findings of Dabire et al. (2016) those who found that TA value was higher in plants treated with organic compounds compared to plants treated with either mineral fertilizers or control. Generally, the TA value of Asala $F_{1}$ tomato in this study is relatively higher than the value reported by Youssef \& Eissa (2016) who found that the TA value of tomato (Egyptian local variety) ranged from 0.22 $0.39 \%$, but is lower compared to the TA value (7.72 to $8.81 \%$ ) of Mongal $F_{1}$ tomato reported by Dabire et al. (2016). These variations in TA value could be justified based on the different tomato varieties tested (Dabire et al., 2016). On the other hand, compost types enriched with moderate and higher rates of sheep manure $(\mathrm{C} 3, \mathrm{C} 4$, and $\mathrm{C5})$ increased juice volume in comparison with $\mathrm{C} 1$ and $\mathrm{C} 2$ compost types (Table 5). Gutierrez-Miceli et al. (2007) and Azarmi et al. (2008) indicated that tomatoes grown in soil amended with sheep-manure vermicompost were ideal for juice production, with soluble solids $>4.5 \%$ and $\mathrm{pH}<4.4$.

\section{Conclusions}

Amending sandy soils with composted crop waste materials can increase growth and yield of tomato, and improve fruit quality. The compost type consisting of date palm, olive, and maize enriched with $40 \%$ sheep manure significantly increased growth, leaf chlorophyll and mineral contents, yield, and fruit quality of tomato. Compared to compost amended with NPK fertilizer, compost amended with sheep-manure at different rates improved the performance of tomato and its nutrient status. These results showed variations in the response of tomato Asala variety to each compost type, but significant differences in growth, yield, and fruit quality characteristics of tomato were observed when compost materials were amended with high rates of sheep manure (20-40\%) in comparison with those amended with mineral NPK fertilizer. Therefore, our results indicate that amending sandy soils with composted crop waste materials enriched with higher rates of sheep manure (20-40\%) can increase growth, yield, and fruit quality of tomato, in addition to reducing the cost of using chemical fertilizers.

\section{Acknowledgement}

The authors would like to express great thanks to the King Abdulaziz City for Science and Technology (KACST) program, Saudi Arabia, for the financial support toward the study of the impacts of organic farming and integrated biological control in Saudi Arabia agriculture.

\section{Conflict of Interest}

The authors declare that they have no conflict of interests.

\section{References}

Abafita R, Shimbir T, Kebede T (2014) Effects of different rates of vermicompost as potting media on growth and yield of tomato (Solanum lycopersicum L.) and soil fertility enhancement. Sky 
Journal of Soil Science and Environmental Management 3: 073-077.

Ahirwar CS, Hussain A (2015) Effect of Vermicompost on growth, yield and quality of vegetable crops. International Journal of Applied Pure Science and Agriculture 1: 49-56.

Alburquerque JA, Gonzalvez J, Garcia D, Cegarra J (2006) Composting of a solid olive-mill by-product ("alperujo") and the potential of the resulting compost for cultivating pepper under commercial conditions. Waste Management 26: 620-626.

AL-Kahtani SH, Ahmed MA (2012) Effect of different mixtures of organic fertilizers on vegetative growth, flowering, fruiting and leaf mineral content of Picual olive trees. American-Eurasian Journal of Agriculture and Environmental Sciences 12: $1105-1112$.

Altieri R, Esposito A (2008) Olive orchard amended with two experimental olive mill wastes mixtures: effects on soil organic carbon, plant growth and yield. Bioresource Technology 99: 8390-8393.

Association of Official Agricultural Chemists (AOAC) (2000) Official methods of analysis. $12^{\text {th }} \mathrm{ED}$. Washington, D. C., USA.

Azarmi R, Ziveh PS, Satari MR (2008) Effect of vermicompost on growth, yield and nutrition status of tomato (Lycopersicum esculentum). Pakistan Journal of Biological Sciences 11: $1797-1802$.

Benito M, Masaguer A, Moliner A, Antonio RD (2006) Chemical and physical properties of pruning waste compost and their seasonal variability. Bioresource Technology 97: 2071-2076.

Chapman HD, Pratt PF (1978) Methods of analysis for soils, plant and water. University of California Division of Agricultural Science, California, Priced Pub. Pp 4034.

Dabire C, Sereme A, Parkouda C, Somda MK, Traore AS (2016) Influence of organic and mineral fertilizers on chemical and biochemical compounds content in tomato (Solanum lycopersicum) var. Mongal F1. Journal of Experimental Biology and Agricultural Sciences 4: 631-636.

Dimitri C, Greene C (2002) Recent growth patterns in the U.S. Organic foods market. USDA Agriculture Information Bulletins No. (AIB-777), Pp 42.

Elouear Z, Bouhamed F, Boujelben N, Bouzid J (2016) Application of sheep manure and potassium fertilizer to contaminated soil and its effect on zinc, cadmium and lead accumulation by alfalfa plants. Sustainable Environment Research 26: 131-135.
Eivazi AR, Rastegarni AR, Habibzadeh Y, Mogaddam A, Khlilzadeh G (2013) Influence of manure fertilizers on morphophysiological traits of tomato (Lycopersicun escutentum Mill). Pakistan Journal of Agricultural Sciences 1: 89-93.

Etissa E, Dechassa N, Alamirew T, Alemayehu Y, Dessalegne L (2014) Response of fruit quality of tomato grown under varying inorganic $\mathrm{N}$ and $\mathrm{P}$ fertilizer rates under furrow irrigated and rainfed production conditions. International Journal of Development and Sustainability 3: 371-387.

Ghehsareh AM, Kalbasi M (2012) Effect of addition of organic and inorganic combinations to soil on growing property of greenhouse cucumber. African Journal of Biotechnology 11: 9102-9107.

Gulshan AB, Saeed HM, Javid S, Meryem T, Atta MI, Amin-udDin M (2013) Effect of animal manure on the growth and development of okra (Abelmoschus esculentus L.). ARPN Journal of Agricultural and Biological Science 8: 213-218.

Gutierrez-Miceli FA, Santiago-Boraz J, Molina JA, Nafate CC, Abud-Archila M, Llaven MAO, Rincon-Rosales R, Dendooven L (2007) Vermicompost as a soil supplement to improve growth, yield and fruit quality of tomato (Lycopersicum esculentum). Bioresource Technology 98: 2781-2786.

Ilupeju EA, Akanbi WB, Olaniyi JO, Lawa BA, Ojo MA, Akintokun PO (2015) Impact of organic and inorganic fertilizers on growth, fruit yield, nutritional and lycopene contents of three varieties of tomato (Lycopersicon esculentum (L.) Mill) in Ogbomoso, Nigeria. African Journal of Biotechnology 14: 2424-2433.

Jackson ML (1973) Soil chemicals analysis. Prentice-Hall, Inc., India. Pp 233.

Jones BJ (1977) Elemental analysis of soil extracts and plant tissue ash by plasma emission spectroscopy. Communications in Soil Sciences and Plant Analysis 8: 349-365.

Jordao CP, Nascentes CC, Cecon PR, Fontes RLF, Pereira JL (2006) Heavy metal availability in soil amended with composted urban solid wastes. Environmental Monitoring and Assessment 112: 309-326.

Joshi D, Hooda KS, Bhatt JC, Mina BL, Gupta HS (2009) Suppressive effects of composts on soil-borne and foliar diseases of French bean in the field in the western Indian Himalayas. Crop Protection 28: 608-615.

Kacar B, Intal A (2008) Plant analysis. Nobel Publication, Ankara. 
Khan AA, Sajid M, Rab A, Alam S, Bari A (2014) Effect of potassium sources on the growth, yield and fruit quality of tomato cultivars. Sarhad Journal of Agriculture 30: 442-450.

Khan, AA, Bibi H, Ali Z, Sharif M, Shah SA, Ibadullah H, Khan K, Azeem I, Ali S (2017) Effect of compost and inorganic fertilizers on yield and quality of tomato. Academia Journal of Agricultural Research 5: 287-293.

Killi D, Kavdir Y (2013) Effects of olive solid waste and olive solid waste compost application on soil properties and growth of Solanum lycopersicum. International Biodeterioration \& Biodegradation 82: 157-165.

Lester GE (2006) Organic versus conventionally grown produce: quality differences and guidelines for comparison studies. HortScience 41: 296-300.

Liu CH, Liu Y, Fan C, Kuang SZ (2013) The effects of composted pineapple residue return on soil properties and the growth and yield of pineapple. Journal of Soil Science and Plant Nutrition 13: 433-444.

Murmu K, Swain DK, Ghosh BC (2013) Comparative assessment of conventional and organic nutrient management on crop growth and yield and soil fertility in tomato-sweet corn production system. Australian Journal of Crop Science 7: 1617-1626.

Nyamangara J, Bergstrom LF, Piha MI, Giller KE (2003) Fertilizer use efficiency and nitrate leaching in a tropical sandy soil. Journal of Environmental Quality 32: 599-606.

Pane C, Celano G, Piccolo A, Villecco D, Spaccini R, Palese AM, Zaccardelli M (2015) Effects of on-farm composted tomato residues on soil biological activity and yields in a tomato cropping system. Chemical and Biological Technologies in Agriculture 2: $1-13$.

Parbha KP, Loretta YL, Usha RK (2007) An experimental study of vermin-biowaste composting for agricultural soil improvement. Bioresource Technology 99: 1672-1681.

Polat E, Demir H, Erler F (2010) Yield and quality criteria in organically and conventionally grown tomatoes in Turkey. Scientia Agricola (Piracicaba Brazil) 67: 424-429.
Porra RJ, Thompson WA, Kriedemann PE (1989) Determination of accurate extinction coefficients and simultaneous equations for assaying chlorophylls $\mathrm{a}$ and $\mathrm{b}$ extracted with four different solvents: verification of the concentration of chlorophyll standards by atomic absorption spectroscopy. Biochimica et Biophysica Acta 975: 384-394.

Ramesh P, Singh M, Rao SA (2005) Organic farming: Its relevance to the Indian Contex. Current Science 88: 561-568.

Rigane MK, Medhioub K (2011) Assessment of properties of Tunisian agricultural waste composts: application as components in reconstituted anthropic soils and their effects on tomato yield and quality. Resources, Conservation and Recycling 55: 785-792.

Shadchina TM, Dmitrieva VV (1995) Leaf chlorophyll content as a possible diagnostic mean for the evaluation of plant nitrogen uptake from the soil. Journal of Plant Nutrition 18: 1427-1437.

Snedecor GW, Cochran WG (1980) Statistical methods. Oxford and JBH. Publishing Co. $6^{\text {th }}$ Edition.

Turhan A, Seniz V (2009) Estimation of certain chemical constituents of fruits of selected tomato genotypes grown in Turkey. African Journal of Agricultural Research 4: 1086-1092.

Yogev A, Raviv M, Kritzman G, Hadar Y, Cohen R, Kirshner B, Katan J (2009) Suppression of bacterial canker of tomato by composts. Crop Protection 28: 97-103.

Youssef MA, Eissa MA (2016) Comparison between organic and inorganic nutrition for tomato. Journal of Plant Nutrition: DOI: 10.1080/01904167. 2016.1270309.

Wang XX, Zhao F, Zhang G, Zhang Y, Yang L (2017) Vermicompost improves tomato yield and quality and the biochemical properties of soils with different tomato planting history in a greenhouse study. Frontiers in Plant Scienc8:1978. doi: 10.3389/fpls.2017.01978

Zayed G, Abdel-Motaal H (2005) Bio-active composts from rice straw enriched with rock phosphate and their effect on the phosphorous nutrition and microbial community in rhizosphere of cowpea. Bioresource Technology 96: 929-935. 